Address for Correspondence: Prof. Patrick Honoré,

Head of Clinics and Head of Critical Care Nephrology Platform, Intensive Care Department, University Hospital, Vrije Universiteit Brussel, Brussels, Belgium E-mail: patrick.honore@uzbrussel.be

\begin{tabular}{|l|}
\hline Access this article online \\
\hline $\begin{array}{l}\text { Website: } \\
\text { www.intern-med.com }\end{array}$ \\
\hline DOI: \\
10.1515/jim-2013-0001 \\
\hline Quick Response Code: \\
\hline \\
\\
\end{tabular}

\title{
Embracing western and Chinese research and clinical knowledge: We take up the translational gauntlet!
}

\author{
Patrick Honoré ${ }^{1^{*}}$, Herbert Spapen ${ }^{2}$ \\ ${ }^{1}$ Critical Care Nephrology Platform, ${ }^{2}$ ICU Research Unit, Intensive Care Department, University Hospital, Vrije \\ Universiteit Brussel, Brussels, Belgium
}

With this first issue, we proudly announce the birth of the Journal of Translational Internal Medicine (JTIM). This brandnew journal is a peer-reviewed quarterly publication of the International Society of Translational Sciences and is published online.

As the Editor-in-Chief, we certainly do not intend to add just another journal to an already extended list of open access publications. ${ }^{[1]}$ Rather, we aim to fill in the growing need for a "holistic" viewpoint on many diseases that are now cornered by different clinical (sub) specialties. As critical care physicians, we both are confronted daily with such "specialty overlap". This not only requires up-to-date knowledge of all specialties separately ${ }^{[2,3]}$ but also needs to be constantly imbedded or fine-tuned within a global context of intensive care. Translational medicine also means bridging the gap between pathophysiology of disease and clinical practice. Indeed, basic mechanisms of disease are often not wellappreciated or understood by clinicians. Therefore, the journal will try to offer a more comprehensive insight in the (patho) physiological "basics" of disease processes and to encourage clinicians to translate this knowledge into the most adequate bedside treatment. Accordingly, "bench to bedside" reviews will hold a privileged place in our journal. ${ }^{[4,5]}$

In general, overlapping or interacting medical disorders, e.g., cardiorenal dilemmas, ${ }^{[6]}$ will definitely be "backbone" assets of the JTIM. However, papers covering internal medicine-concerned domains including neurology and acute medicine (intensive care and emergency medicine, trauma, burns and toxicology) are also welcomed. ${ }^{[7]}$ Special emphasis will be accorded to relatively new specialties such as infectiology and hospital hygiene. A special forum is offered to pharmacological issues as research and clinical applications (in particular pharmacodynamics and -kinetics of antimicrobials in general and specific disease conditions) ${ }^{[8]}$ in this field have made considerable progress during the last decade. Finally, the journal will also cover fundamental and clinical studies related to health care, ethical and social issues in the field of medicine whilst keeping an open mind on developments in computer and mechanical engineering. Regarding the format, we accept research papers, review papers, structured reviews, short communications and point-of-views and case reports. Articles of high clinical interest or implication will obviously be given preference.

Another important goal of this novel journal is to construct a bridge between the Western and Chinese scientific and clinical communities. During the last decade, research activity in China has been constantly growing. Today, it has reached an outstanding level that equals or even surpasses Western quality standards, especially in acute medicine. ${ }^{[9]}$ Whereas Western physicians dedicate a large part of their time to clinical research, their Chinese counterparts excel in animal research. The JTIM intends to emphasize and strengthen this complementary link between the Chinese en Western world within the scope of one publication that collects and shares each other's insights and experiences. We are proud to present an editorial board composed of renowned experts in basic 
and clinical research who accepted to join us in turning this exciting project into a large success. Among them, many eminent Chinese clinicians and scientists are represented. We are indebted to Professor Jian Kang from the China Medical University (Shenjang, China) who will shoulder Professor Patrick Honore (VUB University, Brussels, Belgium) as Adjunct Editor-in-Chief. A special mention goes to our managing editor, Professor Andrew Ren. He is the driving force behind our project by taking care of all small and large business issues related to an open access journal.

Launching a journal in 2013 implies using modern tools of communication. Indeed, the "open access" formula provides more fluid dissemination of scientific information as articles can be freely downloaded from any place in the world. Both our publishers, Spring Media Publishing and Medknow, are professionals in journal publishing. Being part of Wolters Kluwer Health (Philadelphia, USA), Medknow is one of the largest open access publishers world-wide harboring over 200 medical journals. Wolters Kluwer Health is a leading global provider of information, business intelligence and point-of-care solutions for the health care industry and serves more than 150 countries and territories world-wide. Wolters Kluwer Health customers include professionals, institutions and students in medicine, nursing, allied health and pharmacy. Major brands include Lippincott Williams \& Wilkins, Ovid ${ }^{\circledR}$, UpToDate ${ }^{\circledR}$, Medi-Span ${ }^{\circledR}$, Facts \& Comparisons ${ }^{\circledR}$, Pharmacy OneSource ${ }^{\circledR}$, Lexicomp ${ }^{\circledR}$ and ProVation ${ }^{\circledR}$ Medical. Wolters Kluwer Health is part of the Wolters Kluwer group, a market-leading global information services company, employing approximately 19,000 people world-wide and operating in more than 40 countries across Europe, North America, Pacific Asia and Latin America. They not only agreed to launch the journal, but also constructed a very comprehensive website (accessible at www.intern-med.com) and online submission system (accessible at www.journalonweb. $\mathrm{com} / \mathrm{jtim})$. Articles will be submitted through this website only. In line with an open access philosophy, no charges will be accounted for submission, processing or publication of manuscripts, not even for color photograph reproductions. Within few years, we intend to become recorded and cited in the major scientific and medical databases.

We strongly believe that all tools are gathered to make this new journal a valuable and highly appreciated source of information and knowledge for clinicians and scientists all over the world. Godspeed JTIM!

\section{REFERENCES}

1. Fowler AJ, Agha RA, Camm CF, Littlejohns P. The UK Freedom of Information Act (2000) in healthcare research: A systematic review. BMJ Open 2013;3:e002967.

2. Yee J. Newphrologist: The intensive care kidney specialist. Adv Chronic Kidney Dis 2013;20:1-3.

3. Cooper MS, Venkatesh B. Endocrine management in the intensive care unit. Preface. Best Pract Res Clin Endocrinol Metab 2011;25:703-4.

4. Colli A, Fraquelli M, Casazza G, Conte D, Nikolova D, Duca P, et al . The architecture of diagnostic research: From bench to bedside clinical guidelines using liver stiffness as an example. Hepatology 2013. [Epub ahead of print]

5. Psaltis PJ, Spoon DB, Wong DT. Utility of mesenchymal stromal cells for myocardial infarction. Transitioning from bench to bedside. Minerva Cardioangiol 2013;61:639-63.

6. Cruz DN. Cardiorenal syndrome in critical care: The acute cardiorenal and renocardiac syndromes. Adv Chronic Kidney Dis 2013;20:56-66.

7. Kellett J. Acute hospital medicine - A new sub-speciality or internal medicine re-born? Eur J Intern Med 2011;22:334-8.

8. Udy AA, Roberts JA, Lipman J. How should we dose antibiotics for pneumonia in the ICU? Curr Opin Infect Dis 2013;26:189-95.

9. Li W, Qian J, Liu X, Zhang Q, Wang L, Chen D, et al. Management of severe crush injury in a front-line tent ICU after 2008 Wenchuan earthquake in China: An experience with 32 cases. Crit Care 2009;13:R178.

How to cite this article: Honoré $\mathrm{P}$, Spapen $\mathrm{H}$. Embracing western and Chinese research and clinical knowledge: We take up the translational gauntlet! J TransI Intern Med 2013; 1(1): 1-2.

Source of Support: Nil, Conflict of Interest: None declared 